\title{
Penerapan Model Pembelajaran Kooperatif Tipe NHT Berbantuan Alat Peraga Sistem Pernapasan Manusia
}

\section{Application of Cooperative Learning Models NHT Types Assisted by Human Respiration Models}

\author{
Nonci M. Uki ${ }^{1 *}$ \\ ${ }^{1}$ STKIP SoE, Jl. Badak No. 5A, Lokasi 2 SMK N. 2 SoE, SoE, Indonesia \\ *Corresponding authors: noncimelindauki@gmail.com
}

Manuscript received: ......... Revision accepted:

\begin{abstract}
Hasil observasi di beberapa sekolah di Kabupaten Timor Tengah Selatan (TTS) menunjukkan bahwa hasil belajar yang diperoleh siswa masih di bawah kriteria ketuntasan minimum (KKM). Hal ini disebabkan karena keterbatasan kreativitas guru dalam memilih metode yang tepat dalam proses pembelajaran, dan masih banyak guru yang belum memanfaatkan media pembelajaran sehingga siswa merasa bosan dan pada akhirnya berpengaruh pada hasil belajar siswa. Penelitian ini bertujuan untuk Menganalisis keefektifan model pembelajaran kooperatif tipe NHT dan Konvensional berbantuan alat peraga terhadap hasil belajar siswa pada materi sistem pernapasan manusia. Metode penelitian yang digunakan adalah Quasi Experiment dengan desain Nonequivalent Control Group Design yang melibatkan dua kelas, yaitu kelas yang menggunakan model pembelajaran NHT dan Konvensional. Data dikumpulkan melalui tes hasil belajar dan dianalisis menggunakan uji N-Gain. Hasil penelitian menunjukkan bahwa rata-rata hasil belajar kelompok NHT $(0,70)$ dan Konvensional $(0,57)$. Penggunaan model pembelajaran kooperatif tipe NHT berbantuan alat peraga lebih efektif meningkatkan hasil belajar siswa dibandingkan model Konvensional.
\end{abstract}

Keywords: Alat Peraga, Hasil Belajar, NHT.

\section{PENDAHULUAN}

Hasil observasi di beberapa sekolah di Kabupaten Timor Tengah Selatan (TTS) menunjukkan bahwa hasil belajar yang diperoleh siswa masih di bawah kriteria ketuntasan minimum (KKM). Hal ini disebabkan karena keterbatasan kreativitas guru dalam memilih metode yang tepat dalam proses pembelajaran dan masih banyak guru yang belum memanfaatkan media pembelajaran sehingga siswa merasa bosan dan pada akhirnya berpengaruh hasil belajar siswa.

Materi sistem pernapasan pada manusia merupakan materi yang bersifat abstrak dan berkaitan dengan mekanisme serta proses yang terjadi di dalam tubuh, sehingga sulit bagi siswa untuk memahami materi tersebut. Oleh karena itu, untuk membantu siswa dalam memahami materi sistem pernapasan pada manusia maka dalam proses pembelajarannya diperlukan bantuan alat peraga.

Pembelajaran dengan menggunakan alat peraga merupakan suatu rangkaian kegiatan untuk menyampaikan materi pelajaran yang bertujuan memberi kesempatan kepada siswa untuk aktif belajar, sehingga memungkinkan siswa memperoleh pengetahuan untuk memecahkan permasalahan yang dihadapi seperti bertanya terhadap sesuatu yang belum dipahami.

Alat peraga

dapat menjelaskan/menunjukkan/membuktikan konsep-konsep atau gejala-gejala yang dipelajari. Pemanfaatan alat peraga diharapkan mampu mengurangi kesulitan yang dialami siswa dan membantu guru dalam pembelajaran sehingga penyampaian konsep lebih bermakna dan dapat meningkatkan pemahaman siswa terhadap konsep yang dipelajarinya, dengan demikian akan tercipta suatu proses pembelajaran yang berkualitas.

Hasil observasi di SMA Efata SoE dalam pembelajaran biologi terutama materi sistem pernapasan pada manusia, ternyata proses pembelajarannya berpusat pada buku paket yang sudah ada, belum memanfaatkan media pembelajaran berupa alat peraga dan kurang memberikan kesempatan kepada siswa untuk beraktivitas dalam proses pembelajaran sehingga motivasi dan hasil belajar siswa rendah.

Katili (2009) mengemukakan bahwa kebiasaan guru dalam menyampaikan materi pelajaran masih cenderung menggunakan metode konvensional yaitu guru sebagai pusat pembelajaran. Guru cenderung menulis di papan tulis, ceramah, dan siswa mencatat, sehingga motivasi dan hasil belajar siswa di bawah KKM yang sudah ditentukan.

Seiring berkembangnya ilmu pengetahuan dan teknologi, maka perlu adanya perubahan pendekatan pembelajaran yang semula teacher centered menjadi student centered. Pembelajaran secara klasikal yang berubah menjadi pembelajaran kooperatif, bertujuan untuk memaksimalkan kerja sama antar siswa dengan latar belakang dan kemampuan yang heterogen dalam kelompok-kelompok kecil. Oleh karena itu, guru diharapkan mengurangi dominasi di dalam kelas, siswa harus aktif berpartisipasi menemukan dan membentuk sendiri pengetahuannya. Ada berbagai model pembelajaran 
kooperatif, di antaranya adalah model pembelajaan kooperatif tipe Numbered Head Together (NHT).

Metode NHT yang merupakan metode belajar kelompok yang diawali dengan pemberian nomor kepada setiap anggota kelompok, nomor-nomor tersebut yang akan menjadi identitas siswa dalam proses pembelajaran. Ciri khas dari NHT yaitu guru hanya menunjuk siswa dengan menyebutkan salah satu nomor yang mewakili kelompoknya untuk mempresentasikan hasil kerja kelompoknya. Hal ini merupakan upaya sangat baik untuk meningkatkan tanggung jawab individu dalam diskusi kelompok, serta adanya saling ketergantungan antara sesama individu dalam kelompok.

Berdasarkan hasil penelitian Jamalong (2012) menyimpulkan bahwa hasil belajar siswa yang menggunakan model kooperatif tipe NHT lebih baik dari pada dengan model konvensional. Sejalan dengan penelitian yang dilakukan oleh Siregar (2012) dalam penelitiannya menyimpulkan bahwa penggunaan model pembelajaran kooperatif tipe NHT berpengaruh secara signifikan terhadap hasil belajar siswa. Hal ini ditunjukkan dengan perolehan nilai rata-rata postest di kelas eksperimen sebesar 77,4. Sedangkan di kelas kontrol diperoleh nilai rata-rata postest sebesar 69,9. Artinya terdapat perbedaan rata-rata nilai postest antara kelas eksperimen dan kelas kontrol. Selain meningkatkan hasil belajar siswa, model pembelajaran kooperatif tipe NHT ternyata dapat meningkatkan aktivitas belajar siswa. Hal ini ditunjukkan dari hasil pengamatan yang dilakukan oleh observer, diperoleh bahwa aktivitas siswa mengalami peningkatan yang positif.

Sehingga dapat disimpulkan bahwa pembelajaran dengan menggunakan model NHT memberikan hasil belajar yang lebih baik dari pada dengan model konvensional (Sunandar 2008). Berdasarkan uraian tersebut perlu dilakukan penelitian tentang Penerapan model pembelajaran kooperatif tipe NHT berbantuan alat peraga sistem pernapasan manusia.

Berdasarkan latar belakang masalah di atas maka rumusan masalah dalam penelitian ini yaitu apakah penerapan model pembelajaran kooperatif tipe NHT berbantuan alat peraga sistem pernapasan dapat meningkatkan hasil belajar siswa?

Berdasarkan rumusan masalah diatas maka tujuan dari penelitian ini yaitu untuk mengetahui peningkatan hasil belajar siswa dengan penerapan model pembelajaran kooperatif tip NHT berbantuan alat peraga.

\section{METODE}

Rancangan penelitian menggunakan quasi experimental. jenis penelitian yang digunakan adalah penelitian eksperimen untuk membandingkan perlakuan belajar mengajar pada kelas eksperimen dan kelas kontrol. desain penelitian yang digunakan adalah nonequivalent control group design, sugiyono (2012).
Tabel 1. Pola rancangan penelitian

\begin{tabular}{cccc}
\hline Kelompok & $\begin{array}{c}\text { Pre } \\
\text { test }\end{array}$ & Perlakuan & $\begin{array}{c}\text { Post } \\
\text { test }\end{array}$ \\
\hline $\mathrm{E}$ & $\mathrm{O}$ & $\mathrm{X} 1$ & $\mathrm{O}$ \\
& $\mathrm{O}$ & $\mathrm{X} 2$ & $\mathrm{O}$ \\
$\mathrm{K}$ & $\mathrm{O}$ & $\mathrm{X} 3$ & $\mathrm{O}$ \\
\hline
\end{tabular}

Sumber: (Sugiyono, 2012)

Populasi dalam penelitian ini adalah seluruh siswa kelas X1 SMA Efata SoE yang terdiri dari empat kelas yang berjumlah 90 siswa. Pengambilan sampel dalam penelitian ini menggunakan Cluster random sampling diambil 3 kelas yang berjumlah 60 siswa, untuk menentukan kelas kontrol dan kelas eksperimen. kelas IPA 2 mendapatkan perlakuan dengan model pembelajaran kooperatif tipe NHT

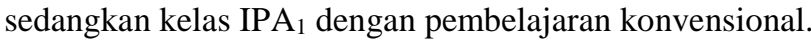

Analisis statistik yang digunakan dalam penelitian ini yaitu menggunakan analisis N-Gain. Analisis gain digunakan untuk mengetahui peningkatatan hasil belajar kognitif siswa sebelum dan setelah diberikan perlakuan.

Tabel 2. Kriteria indeks Gain

\begin{tabular}{cc}
\hline Batasan & Kategori \\
& \\
\hline $0,7<\mathrm{g} \leq 1$ & Tinggi \\
$0,3<\mathrm{g} \leq 0,7$ & Sedang \\
$0,0<\mathrm{g} \leq 0,3$ & Rendah \\
\hline
\end{tabular}

\section{HASIL DAN PEMBAHASAN}

Peningkatan hasil belajar kognitif siswa dibuktikan dengan analisis gain. Perbedaan rata-rata kedua kelas perlakuan disajikan dalam table dibawah ini

Tabel 3. Perbedaan Rata-Rata hasil Belajar Siswa Kelas Kontrol dan Perlakuan

\begin{tabular}{cccc}
\hline $\begin{array}{c}\text { Model } \\
\text { Pembelajaran }\end{array}$ & $\begin{array}{c}\text { Jumlah } \\
\text { siswa }\end{array}$ & $\begin{array}{c}\text { Rata- } \\
\text { rata }\end{array}$ & Kriteria \\
\hline NHT & 30 & 0,70 & Tinggi \\
Konvensional & 30 & 0,57 & Sedang \\
\hline
\end{tabular}

Peningkatan hasil belajar siswa dapat dibuktikan dengan analisis gain. Terlihat pada Tabel di atas menunjukkan bahwa rata-rata peningkatan hasil belajar kognitif siswa yang diajar dengan metode NHT memiliki peningkatan yang lebih efektif dibandingkan dengan kelas Konvensional.

Hal ini dimungkinkan karena pada kelas NHT dengan penomoran menjadikan siswa lebih aktif dan bertanggungjawab dengan segala aktivitasnya. Pengajaran kooperatif lebih menekankan pembelajaran yang berpusat pada siswa (student centered learning) disertai unsur-unsur penanaman sikap siswa antara lain, jujur, peduli, disiplin, 
tanggung jawab, berani, menghargai, aktif, percaya diri, dan kerjasama dalam kelompok.

Campbell (2013) menyatakan nilai-nilai moral atau sikap siswa harus benar-benar menyatu dan diterapkan dalam keseharian siswa dan juga didalam kelas. Sikap, aktif, berani dan tanggung jawab siswa pada kegiatan diskusi presentasi terlihat dengan banyak siswa yang terlibat aktif bertanya, menjawab pertanyaan maupun memberikan tanggapan terkait materi sistem pernapasan pada manusia. Hal ini didukung pernyataan Rustaman (2005) yang menyatakan bahwa pembelajaran aktif dan menarik dapat merangsang tumbuhnya sikap ilmiah, jujur, kerja sama dan bertanggung jawab. Cara ini menjamin keterlibatan total semua siswa dan upaya yang sangat baik untuk meningkatkan tanggung jawab individual dalam diskusi kelompok. Keterlibatan total semua siswa tentunya akan berdampak positif terhadap hasil belajar siswa.

Peningkatan hasil belajar kognitif juga tidak terlepas dari penggunaan media pengajaran berupa alat peraga sederhana pada materi sistem pernapasan. Penggunaan alat peraga sederhana, siswa lebih mudah memahami materi pelajaran. Selain itu siswa lebih termotivasi untuk belajar karena pembelajaran yang tidak monoton. Hal ini sesuai dengan pendapat Sudjana (2000) bahwa media pengajaran dalam proses belajar menyebabkan pengajaran lebih jelas maknanya sehingga dapat lebih dipahami oleh siswa dan memungkinan siswa menguasai dan mencapai tujuan pengajaran serta membuat pengajaran lebih menarik perhatian siswa sehingga dapat menumbuhkan motivasi belajar siswa.

Hasil belajar yang diperoleh dimungkinkan dipengaruhi oleh adanyan faktor eksternal yang berupa media pembelajaran dan lingkungan yang mendukung. Kondisi internal siswa pun mempengaruhi hasil belajar misalnya jika siswa mempunyai kondisi fisik yang baik, emosional yang baik, dan kemampuan bersosialisasi yang baik maka siswa tersebut tidak akan mengalami kesulitan dalam mempersiapkan diri untuk mengikuti pembelajaran. Sehingga dapat disimpulkan bahwa tercapainya hasil belajar siswa yang optimal dalam proses pembelajaran dipengaruhi oleh kondisi internal serta eksternal siswa. hal tersebut sesuai dengan pendapat Anni et al (2005), bahwa kondisi eksternal seperti variasi pembelajaran dan lingkungan belajar serta kondisi internal yang mencakup fisik, kemampuan intelektual, emosional dan kondisi sosial akan mempengaruhi kesiapan, proses, dan hasil belajar.

Metode NHT yang digunakan selama penelitian ini dampak positif tentunya menguntungkan bagi siswa. Berdasarkan pengamatan peneliti seluruh siswa terlibat aktif pada saat diskusi karena langkah-langkah yang digunakan dalam model pembelajaran NHT adalah penomoran dimana guru hanya menunjuk seorang siswa yang mewakili kelompoknya tanpa memberitahu terlebih dahulu siapa yang mewakili kelompoknya tersebut. Sehingga cara ini menjamin keterlibatan total semua siswa dan upaya yang sangat baik untuk meningkatkan tanggung jawab individual dalam diskusi kelompok.

Penelitian ini juga menunjukan bahwa, hasil belajar siswa yang diberikan perlakuan NHT lebih efektif dibandingkan dengan kelompok Konvensional terlihat dari nilai kognitif siswa. Tercapainya hasil belajar kognitif siswa dipengaruhi oleh model pembelajaran yang digunakan dalam kelas.

\section{SIMPULAN}

Berdasarkan hasil penelitian maka disimpulkan bahwa model pembelajaran kooperatif tipe NHT paling efektif dari model konvensional.

\section{UCAPAN TERIMAKSIH}

Jurnal ini dipersembahkan kepada:

1. STKIP SoE

2. Program Studi Pendidikan Biologi STKIP SoE

3. Keluarga Tercinta

\section{DAFTAR PUSTAKA}

Anni CT., Rifa'i A. E., Purwanro \& Purnomo D. 2005. Psikologi Belajar. Semarang

Campbell, E. 2003. The Ethical Teacher. New York: Open University Press.

Jamalong, A. 2012. Meningkatkan Hasil Belajar Siswa Melalui Model Kooperatif Numbered Heads Together (Nht) di Kelas X SMA Negeri 1 Beduai Kabupaten Sanggau. Jurnal pendidikan dan kebudayaan, 18 (4).

Katili, N. 2009. Pengembangan perangkat berorientasi model pembelajaran langsung pada pokok bahasan sistem pernapasan pada manusia di kelas V SD N Ketiteng I Gayungan Surabaya. Jurnal Inovasi, 6 (3): 543.

Rustaman, N. 2005. Perkembangan Penelitian Pembelajaran Berbasis Inkuiri dalam Pendidikan Sains. Makalah Seminar Nasional II Himpunan Ikatan Sarjana dan Pemerhati IPA Indonesia. FPMIPIPA UPI.

Siregar, F.A. 2012. Pengaruh model kooperatif tipe NHT terhadap hasil belajar siswa kelas VIII SMP Negeri Medan. Jurnal Pendidikan Fisika. 1 (1): 2252-732x.

Sudjana N. 2000. CBSA . Dasar-dasar Proses Mengajar. Bandung: PT Sinar Baru Algeandra.

Sunandar. 2008. Pengaruh Model Pembelajaran terhadap Minat dan Hasil Belajar Matematika Siswa Kelas V SDN. Jurnal Varia Pendidikan. 20 (2).

Sugiyono. 2012. Metode Penelitian Pendidikan Pendekatan Kuantitatif,

Kualitatif, dan $R$ \& D. Bandung: Alfabeta. 